\title{
模型輪軸を用いた車輪フランジ乗り上がりの基礎的検討*
}

\author{
南雲 洋 介 $^{* 1}$, 谷藤 克 也*2, 今井純一*3
}

\section{Basic Study of Wheel Flange Climbing Using Model Wheelset}

\author{
Yosuke NAGUMO, Katsuya TANIFUJI*4 and Junichi IMAI \\ ${ }^{* 4}$ Department of Mechanical and Production Engineering, Niigata University, \\ 8050 Ikarashi 2-no-cho, Niigata-shi, Niigata, 950-2181 Japan
}

\begin{abstract}
This paper deals with an experimental study on wheel flange climbing of railway vehicles, which is a major factor leading to derailment. The experiment is carried out using a $1 / 5^{-}$scaled model wheelset of standard gauge on a roller rig. Ramp input of lateral external force acting on the wheelset causes derailment under the condition of fixed attack angle and wheel-load unbalance ratio. Three parameters such as wheel lift, lateral force and wheel load acting on outer rail are measured until the derailment occurs. From these measurements, it is possible to observe the behavior of the wheelset and to understand how the attack angle, the wheel-load unbalance ratio and the lateral external force affect the flange-climb derailment. Then, numerical simulation is carried out using an analytical model developed for the single wheelset. As a result, the flange-climb behavior observed in the experiment can be explained theoretically based on the analytical results, although more improvement is desired on the modeling.
\end{abstract}

Key Words: Analytical Model, Numerical Simulation, Railway, Derailment, Flange Climbing, Scaled Model, Wheelset

\section{1. はじめに}

鉄道車両の脱線は, 走行安全に関わる重要な問題で ある. 近年になっても脱線事故は発生しており，その 主要因の一つに車輪のフランジ乗り上がり(1)がある. 車両が曲線を低速で走行すると, カント超過や出口側 緩和曲線での軌道のねじれなどが原因で前軸外軌側車 輪の輪重が減少する.このとき, 横方向力の作用下で 車輪がレールを乗り越えて脱線することがあり,これ がフランジ乗り上がり脱線と呼ばれる。この現象にお いて脱線に至る過程は, 車輪がフランジ部のみでレー ルと接触して踏面部の荷重が零になる(以下では, こ の状態を車輪浮上がりとも呼ぶ)までと, その後車輪 がレールを乗り上がり脱線するまでの二つの状態に大 別される、特に後者のプロセスについては, 車輪軸の 挙動やそのメカニズムがいまだ十分には解明されてい ないため, さらなる検討が必要であると指摘されてい $ろ^{(2)}$.

\footnotetext{
* 原稿受付 2007 年 2 月 27 日. 改定原稿受付日 2007 年 9 月 11 日.

*1 学生員, 新潟大学大学院自然科学研究科( 950-2181 新潟 市五十風二の町 8050)

*2 正員, フェロー, 新潟大学工学部.

*3 新潟大学工学部.

E-mail : tanifuji@eng.niigata-u.ac.jp
}

本報では, 模型輪軸を用いたフランジ乗り上がり脱 線の実験的な検討を行う. 模型を使用することで, 実 車では再現や観測が困難な脱線現象を比較的簡単に扱 うことができる. 模型実験による最近の研究として は, 永瀬らによるものが報告されている(3). そこでは, 縮尺レールを使用した実験用の軌道上で, 模型の二軸 台車により実際の走行が行われた，また，実寸大の一 軸台車を用いた転走台上の脱線実験が, Braghim ら により報告されている(4). 石田らは，一輪軸の転走モ デルにより, 車両が高速走行する際の高周波輪重変動 下における脱線の解析を行った ${ }^{(5)}$. しかし, フランジ 乗り上がりに大きく影響すると考えられる車輪軸のパ ラメータをそれぞれ独立に変化させ，それら一つ一つ の変化による挙動の違いを検証した研究データは少な く, 模型実験によるさらなる検討の余地があるものと 考える，そこで，本報では，転走試験装置の一軸台車 にさまざまな条件を設定し，脱線に至るまでのフラン ジ乗り上がり挙動を調査する，次いで，解析モデルを 構築して数值シミュレーションを実行し, 実験で得ら れた結果との比較, 検討を行う.

\section{2. 実験}

$2 \cdot 1$ 実験装置 図 1 に実験装置の概略を示す。 
（a ）は正面図，(b ) は平面図である. 一定速度で回転 する軌条輪の上に, 標準軌車両の $1 / 5$ 縮小模型である 一軸台車が置かれている，台車の進行方向は, 平面図 において下向きである. 台車上の荷重は左右方向に自 由に移動させることができ, 左右車輪の輪重比を任意 に設定できる，本報で述べる輪重比とは，車輪軸に外 力の作用していない静的な条件において, 左右の各車 輪荷重を一軸台車重量の $1 / 2$ で除した值であり, 転走

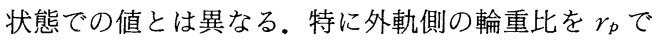
定義し, 以後単に輪重比と述べる場合には外軌側輪重 比 $r_{p}$ を指すものとする. 車輪軸のアタック角 $\psi$ は, リンク機構により任意の値に固定される。車輪軸に作 用する横方向の外力 $Q_{E}$ は, 加圧が可能で輪重への影 響が最も小さい部位として, 軸箱位置を油圧アクチュ エータで押すことにより与える.これらの機構によ り, 車両が曲線を走行しているときに外軌側車輪がフ ランジ接触している状態が模擬される.

実験で測定可能なパラメータは, 車輪浮上がり量と 左右車輪の輪重および横圧である.ここで, 車輪浮上 がり量 $h$ とは, フランジ乗り上がりをする車輪の上昇 量であり, 図 2 に示すように, 光学式変位センサを用 いて当該車輪直上の台車枠の上下変位を測定すること で間接的に求める。横圧と輪重は, 軌条輪の 8 本のス ポークに連続方式(6)で貼ったひずみゲージの出力か

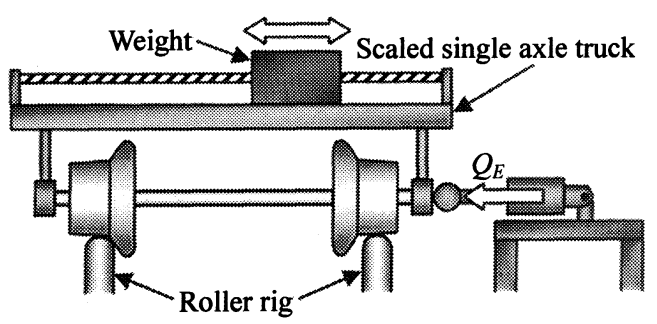

(a) Front view

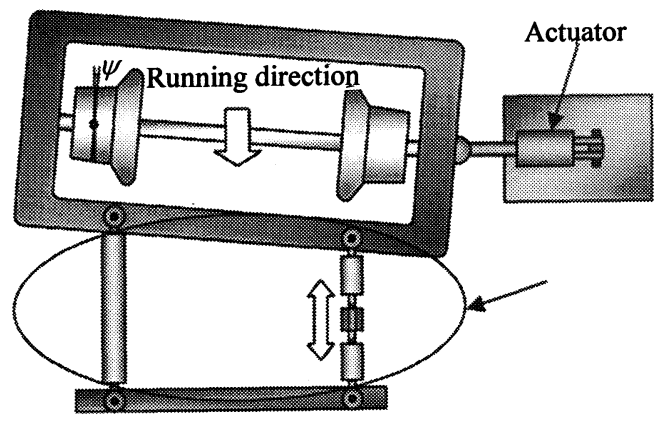

(b) Flan view

Fig. 1 Outline of experimental apparatus
ら算出する.

$2 \cdot 2$ 実験方法 アタック角と輪重比を固定した 状態で, 徐々に横方向外力を増加させてフランジ乗り 上がりを発生させる，走行速度は相似則を用いて，実 車で低速と考えられる $10 \mathrm{~km} / \mathrm{h}$ 相当に設定する．ア タック角 $\psi$ は $5,10,15,20 \mathrm{mrad}$ の四とおりに設定 する。なお，一般的な二軸ボギー車が半径 $200 \mathrm{~m}$ 以上 の曲線を通過する際の定常的なアタック角は, $1 \mathrm{deg}$ (=17.5 mrad) 以下であることが報告されている(7).

輪重比 $r_{p}$ は, 台車重量を左右車輪で等分する 1.0 から設定可能なアンバランスの最大值である 0.3 まで の範囲で 0.1 刻みに固定する. 非常に大きな輪重アン バランスではあるが, フランジ乗り上がりの特徴的な 挙動を把握するために, 本報では極端な条件でも実験 を行うことにする. 外力 $Q_{E}$ は, 初期条件が零で増加 率が $50 \mathrm{~N} / \mathrm{s}$ のランプ入力とする.ただし, 台車軸箱 とアクチュエータとの間にはすきまがあるため最初の 数秒間は外力が作用せず, 実際の外力は図 3 のように 入力される.

測定は外力を加える瞬間から開始し，脱線するまで の車輪軸挙動を観測する。実験結果のばらつきを考慮 して, 各条件では 5 回ずつ測定を行う。

$2 \cdot 3$ 実験結果 実験の測定波形例を示す。図 4 は, 輪重比 $r_{p}=0.7$ についてアタック角ごとに波形を 示したグラフである. 横軸を時間 $t$ として, 図 $4(\mathrm{a})$ に車輪浮上がり量 $h$, (b)に外軌側横圧 $Q$, ( c c )

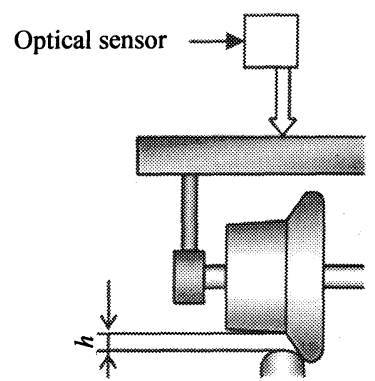

Fig. 2 Measurement of wheel lift

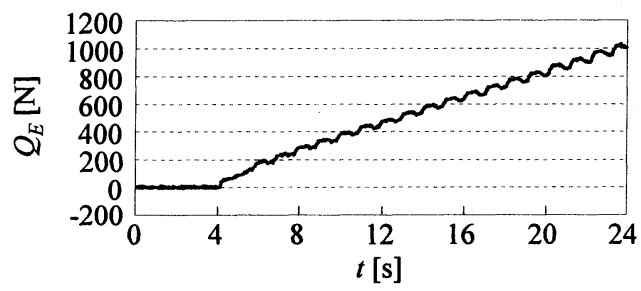

Fig. 3 Lateral external force for experiment 
(d)に外軌側輪重 $P_{o}$ をとる. 図 4(c)，(d)につい ては, 図の煩雑さを避けるため, パラメータを二つに 限って表示した。なお，本報では外軌側車輪の挙動に 注目するため, 内軌側のパラメー夕は省略する.

図 4(a )に示されるように, 時間が経過すると車輪 が浮上がり脱線に至る。脱線は, 浮上がり量 $h$ が模型 車輪のフランジ高さである $6 \mathrm{~mm}$ になったとこで 生じる.アタック角 $\psi$ が増加すると脱線に要する時 間は短くなり， $\psi=15 \mathrm{mrad} と 20 \mathrm{mrad}$ の結果にはほ とんど差がない.

図 4(b)に示される連続方式の横圧波形はゲージが

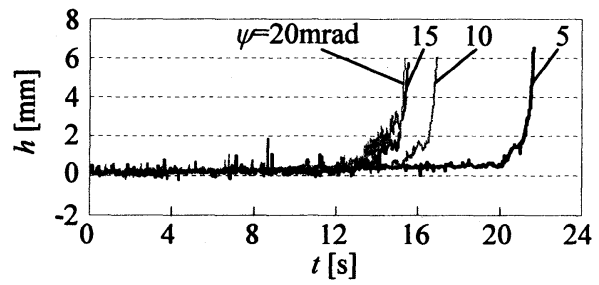

(a) Wheel lift

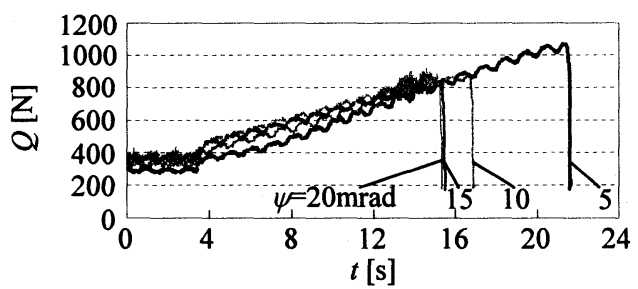

(b) Lateral force

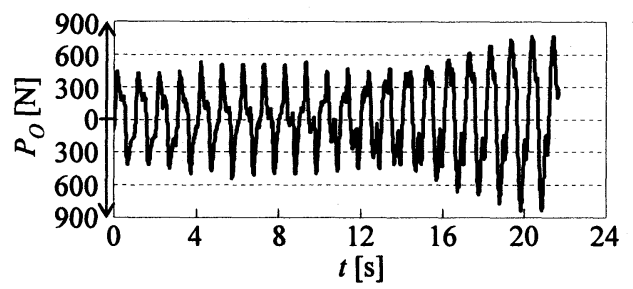

(c) Outer wheel load ( $\psi=5 \mathrm{mrad})$

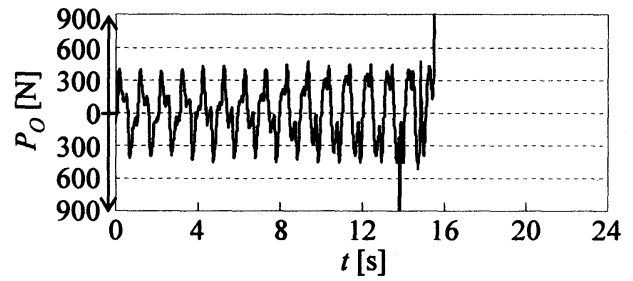

(d) Outer wheel load $(\psi=15 \mathrm{mrad})$

Fig. 4 Experimental results on wheel-rail interaction $\left(r_{p}=0.7\right)$
貼付される軌条輪のスポークの間隔で感度に変動が生 じるが, ピークの値をそのまま横圧值として読み取 る.時間の経過とともに横圧 $Q$ が単調増加しており, $Q$ が急激に減少している点は車輪が脱線したことを 示している，また，脱線に至らない範囲では， $\psi$ が大 きいほど $Q$ が増大している，なお，時間 $t$ が約 4 秒 になるまでは外力 $Q_{E}$ が作用しないため横圧に変動は ない.

図 4(c)と (d)には，それぞれ $\psi=5 \operatorname{mrad}$ と 15 $\operatorname{mrad}$ での外軌側輪重 $P_{0}$ を示す。輪重波形は軌条輪 の 1 回転ごとに正負の值が交互に繰返すため, 零を中

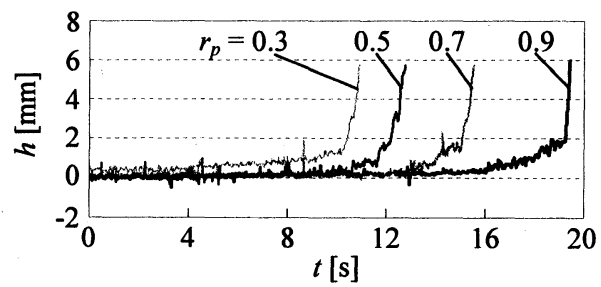

(a) Wheel lift

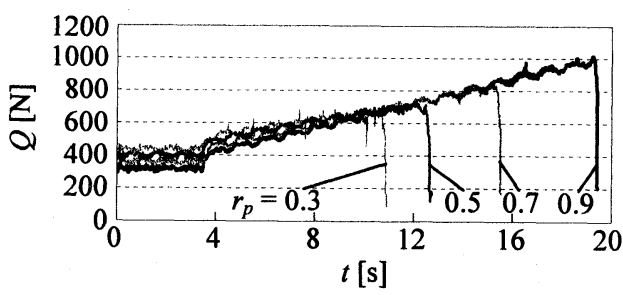

(b) Lateral force

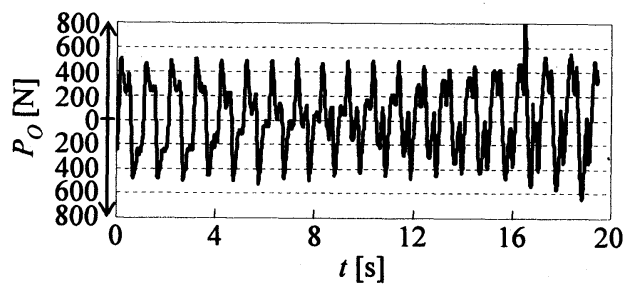

(c) Outer wheel load $\left(r_{p}=0.9\right)$

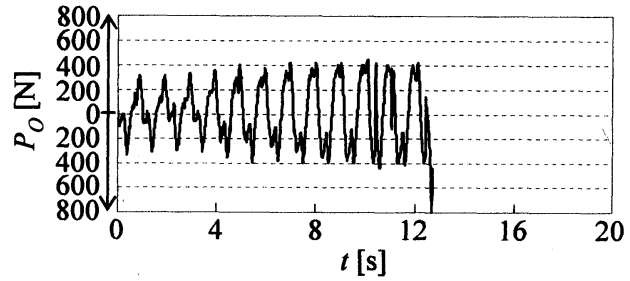

(d) Outer wheel load $\left(r_{p}=0.5\right)$

Fig. 5 Experimental results on wheel-rail interaction $(\psi=15 \mathrm{mrad})$ 
心として上下両方向に正の值で縦軸を表示している。 なお, 本連続方式では, 輪重がノイズの影響を受けや すいことが難点とされており, 実波形とみなされる部 分のピークを滑らかになぞって読み取った。図4(c) の $\psi=5 \mathrm{mrad}$ の場合は, $t$ が小さいときには $P_{0}$ は微 増の傾向にあるが, $t=12 \mathrm{~s}$ 付近でいったんわずかに 減少した後, $t=14 \mathrm{~s}$ 以上では増加の傾向が大きくな る. 一方, 図 $4(\mathrm{~d})$ の $\psi=15 \mathrm{mrad}$ では, $P_{0}$ の大きさ はほとんど変化しないまま脱線している。

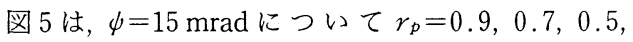
0.3 の波形を示したグラフである. 図 $5(\mathrm{a})$ および (b)から, 輪重比 $r_{p}$ が小さくなるほど脱線に要する 時間は短くなることが示される.図 $5(\mathrm{c})$ と $(\mathrm{d})$ には, それぞれ $r_{p}=0.5$ と 0.9 の場合の外軌側輪重 $P_{o}$ を示 す. 図 $5(\mathrm{c})$ の $r_{p}=0.9$ では, $P_{o}$ の変化は図 $3(\mathrm{c})$ と 同様の傾向であり, (d)の $r_{p}=0.5$ では, 外力が作用 し始める段階から単調増加している。

図 6 は, 横軸を輪重比 $r_{p}$ として, (a)に脱線に要 する外力, (b)に車輪浮上がり時の脱線係数をアタッ ク角ごとにプロットしたグラフである. 図 6(a)で示 されるように, アタック角 $\phi$ の増加と輪重比 $r_{p}$ の減

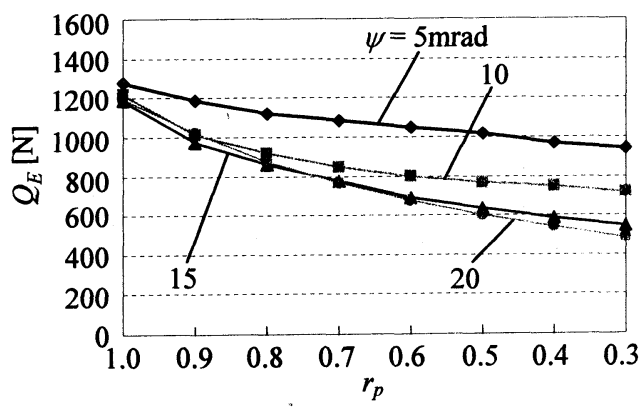

(a) External force

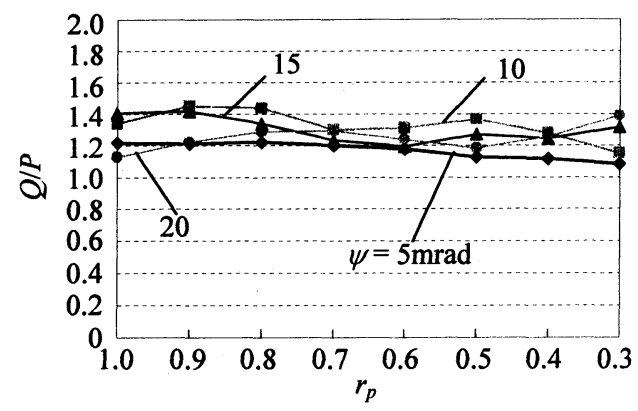

(b) Derailment coefficient

Fig. 6 External force needed for derailment and derailment coefficient at the time of wheel lift, in each wheel-load unbalance ratio $r_{p}$ (in experiment)
少により，脱線に要する外力は小さくなる傾向にあ る.ここで, $r_{p}=1.0$ においてはアタック角の違いに よる差はほとんどないが，rpが小さくなるに従って その差は増大する。図6(b)の $Q / P$ の值では, アタッ ク角 $\psi$ と輪重比 $r_{p}$ の変化による影響には一定の傾向 は認められない. 特に, 図 4 に例示した $r_{p}=0.7$ の場 合， $\psi$ の違いによる $Q / P$ の変動は小さかったことが 示される.ここでは, $\psi$ が小さくなると, 乗り上がり に必要な横力 $Q_{E}$ の増加に応じて輪重 $P$ も増大して いる [式(1)参照].

以上のように，転走装置上の一軸台車を用いて曲線 走行条件で脱線に至るまでの車輪軸挙動が観測され

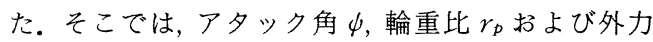
$Q_{E}$ がフランジ乗り上がり現象に及ぼす影響が明らか になった。

\section{3. 数 值 解 析}

$3 \cdot 1$ 車輪軸に作用する力 実験結果に理論的な 考察を加えるために, 解析モデルを構築して数值シミ ュレーションを行う。モデルは一車輪軸として, 実験 に用いた一軸台車と条件を合わせるため, 台車枠の質 量を包含させる．実験と同様にアタック角 $\psi$ は固定 されるため, 左右系のみが考慮される. 車輪軸に左向 きの外力 $Q_{E}$ が作用すると変位し, 左車輪がレールと 2 点接触の状態になる. 中立位置での左右変位を $y=$ 0 とすれば，車輪軸に作用する力は図 7 のように示さ れる。このとき左踏面荷重 $P_{t}$ は, 接触点 $C_{r}$ 点まわ りのモーメントの釣合いより式 ( 1 )で求められる.

$$
P_{l}=\frac{2 b-\left(b_{c}-y\right)}{b} P-\frac{2 b-l}{2 b} P_{f}+\frac{r_{0}}{2 b} Q_{E} \cdots \text { (1) }
$$

ここに, $b$ は左右踏面の接触点間距離の半分, $b_{c}$ は外 軌側踏面接触点と車輪軸重心との距離, $l$ は外軌側踏 面とフランジ接触点との距離，r $r_{0}$ は中立位置における 車輪半径であり, $P$ は車輪軸重量の半分, $P_{f}$ はフラン ジ接触点における上下荷重を表す。

図 8 にはフランジ接触点に作用する力を示す. 図

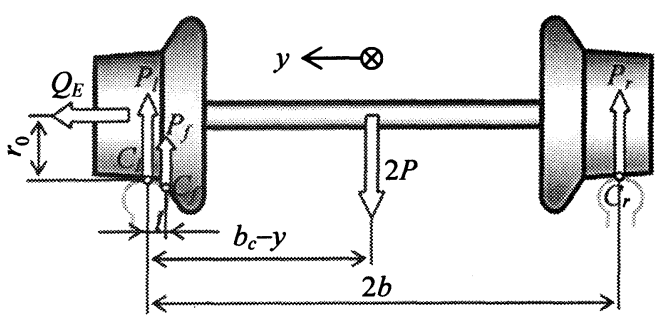

Fig. 7 Forces acting on wheelset 
8（a）は車輪踏面浮上がり前，（b）は浮上がり後の状 態である. 図 $8(\mathrm{a})$ に示すような 2 点接触の状態では, フランジ接触点には外力 $Q_{E}$ と左右の車輪踏面に作用 する横クリープカ $F_{2}\left(=F_{2 t l}+F_{2 t r}\right)$ の和と同じ大きさ のフランジ反力 $Q_{f}$ が発生し, 対応する上下方向成分 $P_{f}$ が次のように導かれる.

$$
P_{f}=\frac{Q_{f}}{\tan \alpha}=\frac{Q_{E}+F_{2 t r}}{\tan \alpha}
$$

フランジ接触する車輪にはアタック角 $\psi$ の存在下て 横クリープ力 $F_{2 t l}$ が作用するため, その横圧 $Q$ はフ ランジ反力 $Q_{f}$ から $F_{2 t l}$ を滅じたものとなる.

$$
Q=Q_{f}-F_{2 t l}=Q_{E}+F_{2 t r}
$$

外軌側輪重 $P_{o}$ は, 次のように $P_{l}$ と $P_{f}$ の和となる.

$$
P_{o}=P_{l}+P_{f}
$$

ここで, 横クリープカは Hertz 理論(8), Kalker の無 次元化係数 ${ }^{(9)}$ を用いて算出し, Lévi-Chartet の式(10) により摩擦力への飽和特性を考慮している。

次に, 踏面荷重 $P_{l}$ が零になった状態が車輪浮上が りで, 図 8(b)にその状態が示される。このとき, 車 輪とレールとの接触点はフランジ部のみになり, そこ に生じる上下方向成分 $P_{f}$ は, フランジ反力 $Q_{f}$ によ るものとフランジ接触点に作用する横クリープカ $F_{2 f}$ の上下方向成分の和となる.

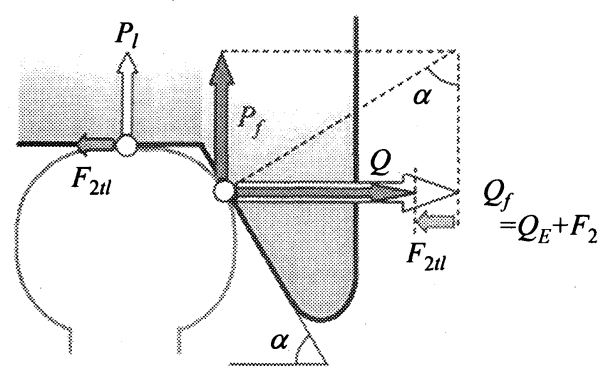

(a) Under condition of 2-point contact

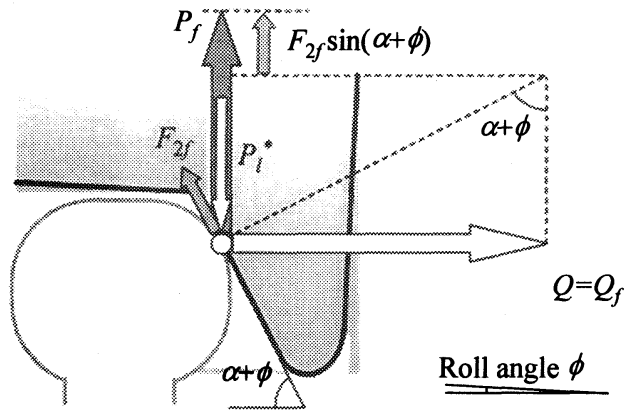

(b) During flange climbing

Fig. 8 Forces acting between wheel and rail

$$
P_{f}=\frac{Q_{f}}{\tan (\alpha+\phi)}+F_{2 f} \sin \alpha
$$

式(5)の上下方向力 $P_{f}$ とフランジ接触点が分担する 車輪軸荷重 $P_{l}^{*}$ との差が上向きの力 $\Delta F$ として作用す る.フランジに平行で上向きを正として, カ $\Delta F$ は式 (6)で表される.

$$
\Delta F=Q_{f} \cos (\alpha+\phi)+F_{2 f}-P_{l}^{*} \sin (\alpha+\phi)
$$

ここで, $\Delta F$ が正になったときにフランジ乗り上がり が発生すると考える。

$3 \cdot 2$ フランジ乗り上がりのモデル化 $3 \cdot 1$ 節の 考え方で求めた力を用いて運動方程式を立てる。車輪 軸の自由度は一般には左右動 $y$ で考えられるが, ここ ではフランジ接触点における挙動に注目し, 図 9 に示 すように右踏面接触点 $C_{r}$ 点まわりのロール $\phi$ として 自由度を変換する。運動方程式は式 ( 7)で表される.

$$
I \ddot{\phi}=(2 b-l) \sin (\alpha+\phi) \times F
$$

ここで, 左辺の $I$ は $C_{r}$ 点まわりの車輪軸の慣性モ一 メント, 右辺の $F$ はフランジに平行に作用する合力 である。合力 $F$ は, 車輪の浮上がり量 $h$ と式 $(6)$ に 示す力 $\Delta F$ の条件により, 以下の五とおりに場合分け される.

Case $1 \quad \Delta F \geq 0: F=\Delta F$

Case $2 h=0, \Delta F<0: F=0$

Case $3 \quad h>0, \Delta F<0,|\Delta F| \geq \mu N$ :

$$
F=\Delta F+\mu N
$$

Case $4 \quad h>0, \Delta F<0,|\Delta F|<\mu N, \dot{h}>0$ :

$$
F=\Delta F-\mu N
$$

Case $5 \quad h>0, \Delta F<0,|\Delta F|<\mu N, \dot{h} \leq 0$ :

$$
F=0
$$

Case 1 のように $\Delta F$ が正の場合には, 合力 $F$ が $\Delta F$ に等しくなり, フランジがレールと粘着して乗り上が る. Case 2 のように車輪が浮上がる前には， $\Delta F$ が

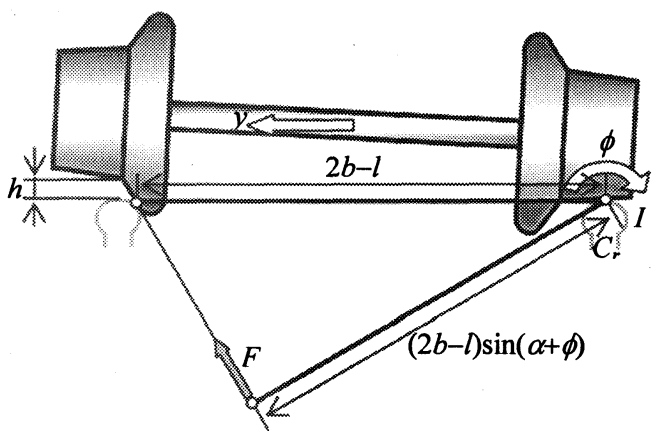

Fig. 9 Analytical model of wheelset for flange climbing 
負でも $h$ に変化はなく, $F$ は零になる. Case 3 から Case 5 は車輪浮上がり後の状態である. Case 3 では 合力 $F$ が負になり車輪が滑り下がる. Case 4 では $F$ は負であるが車輪が上向きの速度をもっていたため, 速度を小さくするように力が作用する. Case 5 では $F$ は零になり車輪の乗り上がりが止まる.

$3 \cdot 3$ 解析方法 モデルの諸元と解析条件は, そ れぞれ実験装置の諸元と実験条件に合わせる。車輪・ レール間の摩擦係数 $\mu$ は, 実験装置にさびや污れが付 着していることを考慮して 0.25 とする.また，フラ ンジ根元部以外ではレールとの接触時間が短く, 摩擦 係数がさらに小さいと予想されるため, $\mu=0.15$ を適 用する。実験と異なり，解析では図 10 に示すように， $t=0 \mathrm{~s}$ からの理想的なランプ入力を作用させる．車輪 浮上がり量 $h$ がフランジ高さである $6 \mathrm{~mm}$ より大き くなったら, 脱線が生じたと判断して解析を終了す る.

$3 \cdot 4$ 実験結果との比較 解析結果と比較しなが ら実験結果に考察を加える。図 11 (a)，（b ），(c)に は, シミュレーション波形のアタック角 $\psi$ ごとの比較 を示す。これらは，それぞれ図 4 ( a )，（b ），(d)の実 験結果に対応している。図 11( a ) より, 車輪浮上がり は実験結果と同様の傾向を示している.ここで， $\psi=$ $15 \mathrm{mrad}$ と $20 \mathrm{mrad} て ゙$ 脱線までの時間の差が小さく なるのは, 横クリープ力が摩擦力に飽和するためであ る.この傾向が実験では特徵的に現れたものと考え る。また, フランジが急速に乗り上がる前に，緩やか な浮上がりが観察され，さらにそれ以前には車輪が $0.5 \mathrm{~mm}$ 程度浮上がった状態が継続している。車輪浮 上がり量が $h=0.5 \mathrm{~mm}$ 程度までは, 車輪とレールの 接触点がフランジ根元部の接触角の小さい部分に存在 するため, 浮上がりが発生しやすくなっている， $h=$ $0.5 \mathrm{~mm}$ 以上では，接触点がフランジの直線部分に移 り接触角が一定になるため, 一時的に浮上がり量の増 大はなくなる. その後, 外力の増加に伴い緩やかにフ ランジ乗り上がりが発生するが，フランジ先端の曲線 部で接触するようになると接触角が減少するため, 急

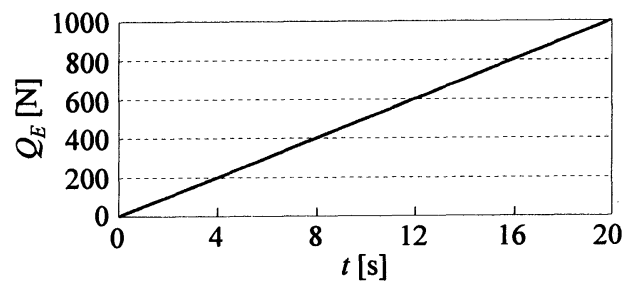

Fig. 10 Lateral external force for numerical simulation
速に脱線に至る。

図 11(b)，（c）の $t=6 \mathrm{~s}$ 前後で輪重 $P_{0}$ がいったん 減少するのは, 摩擦係数の低いフランジ部分に接触点 が移ったためである. それ以後, 増加傾向が大きくな ることについては, 2 点接触時には車輪踏面の上下荷 重を減少させるように作用していたフランジ部の横ク リープ力が, 車輪の浮上がり時には外軌側輪重を増加 させるように作用するためである，実験でも同様の傾 向が現れていることは，このことが原因であると考え られる。なお, 図 4(d)のPoにおいて, この傾向が顕 著に見られないのは，車輪浮上がってから脱線に至る までの時間が短いためである。

図12(a)，(b)，(c)には，シミュレーション波形 の輪重比 $r_{p}$ ごとの比較が示され, それぞれ図 $5(\mathrm{a})$, (c), (d)に対応している. 図 12 にも図 5 と同様の 傾向が示され, 図 12(a), (b)の横方向外力 $Q_{E}$ の増 加に対する挙動の特徵は, 図 11( a ), (b) と同様に説 明される. 図 12 ( c ) については, 外力を加え始める段 階から輪重 $P_{o}$ が単調増加しており, その増加傾向が

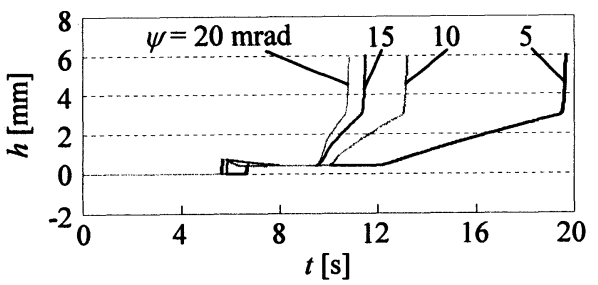

(a) Wheel lift

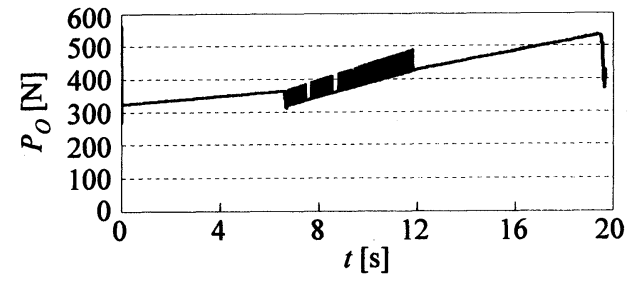

(b) Outer wheel load $(\psi=5 \mathrm{mrad})$

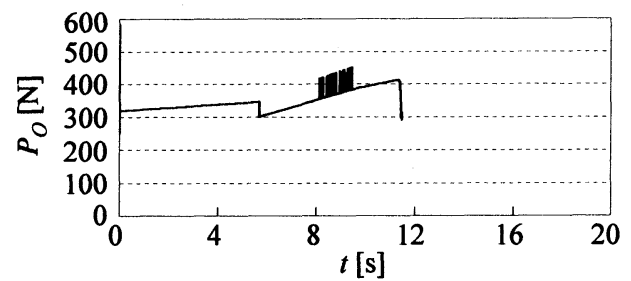

(c) Outer wheel load $(\psi=15 \mathrm{mrad})$

Fig. 11 Analytical results on wheel-rail interaction $\left(r_{p}=0.7\right)$ 


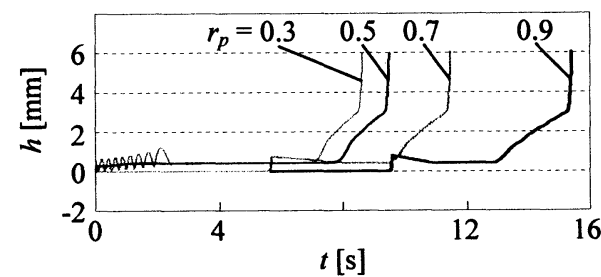

(a) Wheel lift

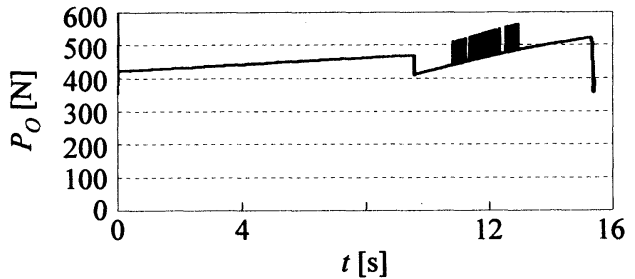

(b) Outer wheel load $\left(r_{p}=0.9\right)$

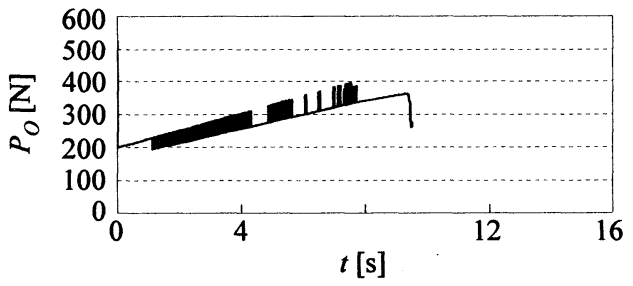

(c) Outer wheel load $\left(r_{p}=0.5\right)$

Fig. 12 Analytical results on wheel-rail interaction $(\psi=15 \mathrm{mrad})$

大きいことについては, 図 12 ( a ) から示されるように 外力の作用なしに車輪が浮上がっていることと, フラ ンジ接触点に作用する横クリープ力によるものであ る.これは，図 $5(\mathrm{~d})$ の実験結果における，外力が作 用し始めた時点からの傾向に対応している.

図 13 には，横軸を輪重比 $r_{p}$ として，（a）に脱線に 要する外力, (b)に車輪浮上がり時の脱線係数をア夕 ック角ごとに示す。これは, 図 6 の実験結果と対応す るグラフである。図 13( a ) から脱線に要する外力は, アタック角 $\psi$ の増加と輪重比 $r_{p}$ の減少により小さく なる傾向が認められる。これは, 図6(a) と同様の傾 向であることから，解析モデルで定性的な模擬ができ ていると考える、ただし，実験では $r_{p}$ が大きいとき にはアタック角の影響が小さく, $r_{p}$ が小さくなるに つれてその影響が大きくなっていくが, 数值シミュレ ーションではその傾向が異なっている.このように， 実験と解析の対応が十分に得られないことについて は，モデル化に不足の部分が残るものと判断される。 また, 図 13(b) からは, 輪重比 $r_{p}$ の変化が脱線係数

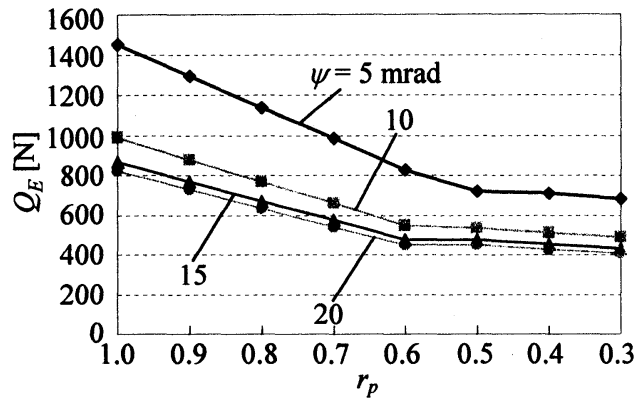

(a) External force

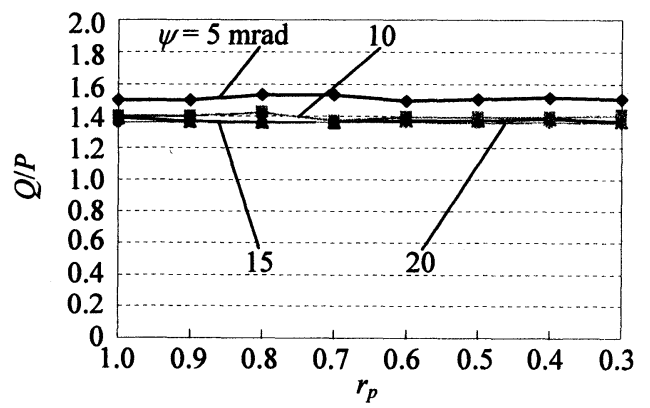

(b) Derailment coefficient

Fig. 13 External force needed for derailment and derailment coefficient at the time of wheel lift, in each wheel-load unbalance ratio $r_{p}$ (in numerical simulation)

$Q / P$ に元る影響はほとんどなく, $Q / P$ は 1.3 から 1.6 の範囲に収まっている. 脱線係数 $Q / P$ の変化に 対する輪重比 $r_{p}$ の影響が小さく，かつ $Q / P$ が狭い範 囲に収まるという点では, 解析は実験と同様の傾向を 示しているが, アタック角 $\psi$ が大きくなると $Q / P$ が 減少する点に関しては害験とは異なっている，なお， 実験では全体的に Q/Pの值が数值シミュレーション よりも小さい.この原因としては, 実験と数值解析で の摩擦係数 $\mu$ の違いが考えられ, 式(8)に示す Nadal の式(11) から模型車輪のフランジ角度 $\alpha=70^{\circ}$ に対して実験に扔ける摩擦係数を逆算すると， $\mu$ はお よそ 0.3 から 0.4 の間で変動していたと推測される.

$$
\frac{Q}{P}=\frac{\tan \alpha-\mu}{1+\mu \tan \alpha}
$$

以上のように,ここで構築したモデルは, 実験結果 に対して理論的な考察を加えることができたものと考 える。

\section{4. まと め}

本報では，フランジ乗り上がりにおける車輪軸の挙 
動解析を目的として, 模型輪軸による脱線実験と数値 シミュレーションを行い, 以下の結果が得られた。

（1）模型実験では, 車輪浮上がり量, 輪重および 横圧を測定することで, 脱線に至るまでの車輪軸の挙 動を観測することができた。

（2）実験結果から, アタック角, 輪重比および横 方向外力がフランジ乗り上がりに及ぼす影響を明らか にした。

（3）数値シミュレーションの結果を実験結果と比 較することにより, 実験のフランジ乗り上がり挙動に 理論的な考察を加えることができた。

以上, フランジ乗り上がりのメカニズム解明に新た な知見が得られたものと考える。なお，構築したフラ ンジ乗り上がりの解析モデルは，車輪軸の挙動を定性 的には模擬することができるものの，実験結果との定 量的なかい離が改善すべき課題として残された.今後 はアタック角によるフランジ部接触点の前方への偏倚 なども考慮して，モデルのさらなる深度化が必要と考 える。

\section{文献}

(1) Maruyama, H. and Kageyama, N., Railway Engineering for Mechanical Engineers (in Japanese), (1981), pp. 117-120, Maruzen.

(2) Railway Accident Investigation Committee, Research
Report on Derailment and Collision Accident at Nakameguro Station of Eidan Subway Hibiya Line (in Japanese), (2000), pp. 1-107, Railway Accident Investigation Committee.

(3) Nagase, K. et al., A Study on Wheel Climb Derailment (1 st Report, Results of Basic Experiments using Model Truck), Transactions of the Japan Society of Mechanical Engineers, Series C, Vol.66, No. 652 (2000), pp. 68-75.

(4) Braghin, F. et al., Experimental and numerical investigation on the derailment of a railway wheelset with solid axle, Vehicle System Dynamics, Vol.44, No. 4 (2006), pp. 305-325.

(5) Ishida, H. et al., Safety Assessment Method of Railway Vehicle under Oscillatory Wheel Load Fluctuation, Transactions of the Japan Society of Mechanical Engineers, Series C, Vol. 71, No. 702 (2005), pp. 100-107.

(6) RTRI ed., Manual for the speed-up test of train on conventional railways (in Japanese), (1993), pp.67-78, RTRI.

(7) Research Committee of MLIT and RTRI, Research Report on Prevention of Flange-Climb Derailment at Low Speed on Sharp Curve (in Japanese), (2004), p. 23, Research Committee of MLIT and RTRI.

(8) Timoshenko, S. P. and Goodier, J. N., Theory of Elas ticity, 3 rd ed., (1970), pp. 414-420, McGraw-Hill.

(9) Kalker, J. J., Survey of Wheel-Rail Rolling Contact Theory, Vehicle System Dynamics, Vol. 8, No. 4 (1979), pp. 317-358.

(10) The Japan Society of Mechanical Engineers ed., Dynamics of railway vehicle (in Japanese), (1994), pp. 20-29, The Society of Electric Vehicles.

(11) p. 118 in Reference (1). 